\title{
POSITING SOCIAL DEVELOPMENT AS THE MAINSTREAM OF GOVERNMENT IMPLEMENTATION IN INDONESIA
}

\author{
Dyah Asri Gita Pratiwi, S.Sos., M.Kesos. \\ Politeknik Kesejahteraan Sosial \\ dyahasrigita@yahoo.com \\ Didit Susiyanto, S.Sos., M.Kesos. \\ PT. Bhumi Jati Power \\ didit.susiyanto@pt-bjp.co.id
}

\begin{abstract}
Abstrak
The environment of governance and development tends to change rapidly, is full of uncertainty, and is full of complexity, so a development policy and strategic programs are needed that are capable of responding carefully to developing problems and challenges. The government must be able to think strategically and visionary, to translate what is thought into effective strategic policies and programs to deal with changes in the surrounding environment, and develop a framework for implementing these strategies in a rational and "grounded" manner through various strategic social development policies and programs.
\end{abstract}

Kata Kunci:

Government; Social Development; Social Policy; Institutional. 


\section{INTRODUCTION}

One of the blessings in disguised of the prolonged crisis that hit the Indonesian nation was the growing collective awareness to rearrange the system of interaction of all components of the nation. This process positions the Indonesian nation in a period of continuous transition and transformation through the search for, structuring a new system and balance between forces or interest groups that are increasingly emerging with all their dynamics. The existence of various turmoil of separatism, national crises and social dynamics, unemployment, poverty, disparities between regions, and the influence of the international environment, implement the life of the nation and state need to be designed as well as possible. The main dimension that becomes a common effort is the management of government policies through social development within the scope of the national and state structures that can respond to and accommodate domestic dynamics that are adaptive to Mondial dynamics.

The environment of governance and development tends to change rapidly, is full of uncertainty, and is full of complexity, so a development policy and strategic programs are needed that are capable of responding carefully to developing problems and challenges. According to Bryson ${ }^{1}$, who termed this volatile and related condition, it requires a response from organizations (government, nongovernment, or society) to think strategically and visionary, translating what is being thought into effective strategic policies and programs to deal with changes in the surrounding environment. and develop a framework for implementing the strategy in a rational and "down to earth" manner through various policies and strategic social development programs.

At the policy level, rearrangement has taken the form of changes and/or the making of various types of laws, government regulations and regional regulations will continue to be produced by making the social policy dimension become the main agenda. At the operational level, restructuring efforts have also been and will continue, starting from the allocation and distribution of resources, strategies, and techniques for the provision of goods and services, as well as ways of managing them more meaningfully in implementing social development.

The restructuring effort requires three pillars as a prerequisite. First, the availability of institutional arrangements in the form of a structured and tiered system of rules of the game, which function to cover and regulate the patterns of interaction between individuals and groups. Second, there is active and proactive involvement of all parties in a structured and tiered manner according to their abilities and capacities and managed in a pattern of interaction to be more focused, efficient, effective, and productive. Third, the existence of community empowerment, through a pattern of interaction between parties that requires relative equality of the parties involved, so that no particular party will dominate the other party, define meanings and values according to their own size, and impose them on other, weaker parties. Do not let society position itself

\footnotetext{
${ }^{1}$ John M.Bryson, Strategic Planning for Public and Non Profit Organizations (San Fransisco: Jossey-Bass Publishrers- Oxford, 1991) page 1
} 
as an object and society will come face to face with other development actors ${ }^{2}$. If that happens, there will be no trust between the community, government, and market mechanisms. This condition is actually counterproductive to the running of government administration and development. For this reason, it is necessary to have an effort that can connect all pillars of government administration so that these pillars can maximize their role ${ }^{3}$.

Thus, the rearrangement of development management through human-centered social development as a new paradigm resulting from a shift in the development paradigm has further insights than just the GNP growth rate or the provision of social services. According to Gran, increasing human development and human welfare, equality and human sustainability is the central focus of the development process, implementing development that determines goals, sources of supervision and to direct the processes that affect their lives (Moeljarto: 1995,35).

The new development perspective gives a special role to government, which is clearly different from the role of government in the growth model. The role of government in this case is to create a social environment that allows humans to develop, namely a social environment that encourages human development and the actualization of human potential to a greater extent. Solving development problems, in addition to economic

\footnotetext{
${ }^{2}$ In the Hegellian perspective, civil society is defined as an independent society so that it can balance the position of the state and the market. Thus, in this Hegellian view, society, the market, and the state are placed in opposite positions and it is likely to cancel each other out.

3 The relationship between development actors is necessary because each development actor has a
}

growth efforts, also requires human-oriented development. Economic development must be in harmony with social development that is focused on humans and the quality of life.

Social development is an approach to improving human welfare, with the main characteristic of trying to harmonize social policy with measures designed to improve economic development. The social approach must be applied in conjunction with the economic approach in the development strategy, which are two sides of the same coin, both must be designed and implemented in a balanced, complementary, complementary, and mutually reinforcing manner. Nancy Birdsall (1993) explicitly states: "social development is economic development".

Social development is carried out based on the system prevailing in development administration in Indonesia. Attention to human beings and their quality of life both as individuals and as members of society towards progress and social change through government policies contained in public policies implemented through a development process is called social policy. Thus, social policy is a form of public policy, social policy is a government decision made to respond to issues of a public nature, namely overcoming social problems or meeting people's needs, many of which are carried out by the government as an effort to improve the quality of human life. In the big line, social policies are

different vision and potential for development. The market/business community, represented by companies and services, has tremendous means and power to define their vision and mission. Thus, the market has such great pressure to influence public decision making. Likewise, the state has considerable power to plan the future direction of society. 
manifested in three categories, namely legislation, social service programs, and taxation systems. Based on this category, it can be stated that every statute, law, or regional regulation concerning social issues and life is a form of social policy, however, not all social policies take the form of legislation (Suharto, 2005).

Initially, social policies that became the thought of social development in Indonesia were only related to the issue of social benefits for disadvantaged communities. Then develop into broader social services (such as education and health). The broader development concerns efforts to address basic social problems, such as poverty, unemployment, and inequality. Then to further sharpen social development, social policy is carried out in a more integrated or unified approach, according to Myrdal's suggestion, who does not want to separate economic development and social development. It is carried out through an integrated approach, namely economic development to pursue growth, but also solving social problems simultaneously through community development. In community empowerment, which is rooted in community participation through community groups to be enabled and independent, not only the individual but also the institutions, so that the stabilization, culture, and practice of democracy is built.

\section{SOCIAL DEVELOPMENT AS THE MAINSTREAM OF DEVELOPMENT POLICY}

Strategic policies and programs are to identify issues as well as alternative solutions

\footnotetext{
${ }^{4}$ Solichin Abdul Wahab, Analisis Kebijaksanaan: dari Formulasi ke Implementasi Kebijaksanaan Negara,
}

in governance and which have urgent and important characteristics to be implemented immediately. Whereas the policy itself is often used interchangeably with other terms such as goals, programs, decisions, laws, provisions, proposals, and big designs for policymakers. According to the United Nations, the policy is interpreted as a guideline for action. These guidelines may be very simple or complex, general and specific, broad or narrow, vague or clear, loose or detailed, qualitative or quantitative in nature, public or private. Policy in this sense may be in the form of a declaration regarding a basis for action, a specific direction of action, a program regarding certain activities, or a plan ${ }^{4}$.

James E. Anderson formulates policy as the behavior of a number of actors (officials, groups, government agencies) or a series of actors in a particular field of activity. Policy refers to a type of action that leads to a specific goal (coerce of actions), which is more or less continuous over time and is expected to maintain certain conditions and is usually intended to fulfill certain conditions which are usually intended to fulfill objectives that are not stated explicitly. in a policy statement. This explanation also explains that the policy is a patterned action that leads to a certain goal and not just a decision to do something.

Within each country, there must be different groups of thought about which direction to choose to achieve this common goal. Each head of state has his own choice in accordance with the real conditions faced by the existing objective conditions. Nothing is truer than anything else - only better. The same thing happened to the level of government in

second edition, Bumi Aksara, Jakarta, 2001, page 2 and look United Nations, 1975. 
the regions. Differences in leaders will lead to different paradigms and ultimately different ways and steps and ultimately difference in public policies taken. Here we meet the different values of each leader in the government where public policy is made ${ }^{5}$.

Returning to the views put forward by Adam Smith and 19th-century political economists, Hayek, Friedman, and others assert that the relationship between public and private space is something that is better defined through the market and the freedom to choose (freedom of choice) rather than through State intervention into the "public interest". During the 1980s and 1990s, the argument that the demarcation between public and private spaces should be left to market forces has become the dominant framework used in public policy theory and practice. The shift from "new" liberalism to "new right" in public policy can be seen clearly through the phenomenon of the emergence of "public sector management" studies and the disappearance of "public administration" studies ${ }^{6}$.

Carl W. Patton and David S. Savicky (1993) clearly explained that policy analysis is the action needed to formulate a policy, either a completely new policy or a new policy as a consequence of an existing policy. Policy analysis is the main activity in policy formulation because it is an effort to provide an initial basis for why the policy should be made. Dunn (1992) defines policy analysis as an applied social science discipline that applies a variety of research methods, in the context of public argumentation and debate, to make

5 Riant Nugroho D, Kebijakan Publik: Formulasi, Implementasi dan Evaluasi, Elex Media Komputindo, Jakarta, 2003, Page 54 critical assessments, and communicate policyrelevant knowledge.

Observing the dynamics of the society in governance and development in Indonesia, there are at least several important issues in the administration of government on a national scale, as challenges that need to be immediately responded to by policy makers, namely:

First, the increasingly uncertain economic conditions, which are reflected in the weakening purchasing power of the people, swelling unemployment and poverty, the weakening rate of investment in the regions, and rising prices for household needs, so that the level of people's welfare has declined further.

Second, the limited sources of funding for governance and development in the regions have resulted in delays in program implementation and unmanagement of various routine activities as well as government and development activities that are deemed important.

Third, inequality between regions. This issue can be seen through the difference in the pace of development between regions, the "rich" and the "poor". The differences in the amount of Balanced Fund Allocation (DAU, DAK, Profit Sharing) received by each region, coupled with differences in the potential and capacity of regional governments between regions, can see the emergence of disparities that tend to be sharper.

Fourth, cooperation between regions. Many problems will be resolved optimally if between regions collaborate to solve these problems, but in reality, in the current era of

\footnotetext{
${ }^{6}$ Wayne Parsons, Public Policy: Pengantar Teori dan Praktik Analisis Kebijakan, Jakarta, June 2005. page 39
} 
regional autonomy, this has not been done much. Some of the issues referred to include the fields of transportation, irrigation, prevention of infectious diseases, staffing, management of marine potential, mining, and handling of supply and demand flows of several commodities between regions/islands.

Fifth, this issue is related to the provision of health, education, clean water, and sanitation services, limited central sectoral program input, and the concentration of APBD allocations to sectors that do spur PAD rather than sectors (basic social) that "use up" PAD funding sources. / APBD. This condition will appear to be getting worse in relatively remote areas. Indications of the deteriorating quality of human life can be seen from the human development index (HDI) figures for 2009. This year the human development index has dropped dramatically as a result of health services, education, and especially people's purchasing power, which have dropped dramatically.

Sixth, issues related to regional potential information systems and investment opportunities that have not been properly tapped, an entrepreneurial mentality in the bureaucracy that is lacking, and marketing that is not supported by good national and international networking. In this context, the process of increasing the capacity of regional officials and developing effective instruments so that the regions are able to map, process, and promote the potential of their regions. Therefore, the information system developed must be able to bridge communication in order to promote regional potential.

\footnotetext{
${ }^{7}$ Jemes B. Whittaker, The Government Performance and Results Act of 1993 : A mandate for Strategic Planning and Performance Measurement (Arlington,
}

One of the stages in the process of formulating policies and strategic programs is the environmental assessment of the organization through the process of analyzing the organization's strategic environment. According to James B. Whittaker ${ }^{7}$, the external environment includes opportunities (Opportunities) and Threats (Threats). Opportunities are situations and factors outside the organization that are positive, which help the organization to achieve or enable it to achieve its vision and mission. Threats are negative factors outside the organization, which can result in the organization failing to achieve its vision and mission.

Internal environment, including Strengths (Strengths) and Weaknesses (Weaknesses) of the organization. Strengths are situations and internal capabilities that are positive, which enable the organization to fulfill strategic advantages in achieving its vision and mission. Weaknesses are situations and internal inadequacies that result in the organization being unable or failing to achieve its vision and mission.

Analyzing the external and internal environment means investigating an event in a strategic environment to find out its causes and or to describe its parts. External Environmental Analysis (ALE) is made by first observing the existing scanning in the external environment of the organization which includes factors, which Bryson grouped into 3 parts, namely: First, trends which include political, economic, social trends. , and technology; Second, partners or customers (client/customers); Third, competitors which include the strength

Verginia : Educational Services Institute, 1995). P 3340. 
of competition and the strength of collaboration.

In line with Bryson, Whittaker ${ }^{8}$ divided it into 8 aspects of ALE, namely:

1. Economic Environment, is a vulnerability for most organizations, and the analysis is the most difficult to do because it involves national scale economies (for example state finances, inflation, interest rates, fluctuations in the rupiah exchange rate, etc.);

2. Technological Environment, which is no less important than the economic environment. The very rapid technological advances in the last decades of the twentieth century require organizations to always keep up with these technological changes so that they can run effectively and efficiently;

3. Social Environment, is the most important in organizational life because it involves social behavior and cultural values (social attitude and values). Transparency is a new demand, while public criticism must be heeded, and there is an increasingly intense demand for an increase in quality of life;

4. Political Environment, which are government policies related to the field of organizational activities, for example, taxation, monetary, licensing policies, which have a long-term impact on organizational effectiveness. This will be felt in organizations whose fields of activity have been regulated by the Government because these organizations will depend on the political life of the government;

5. Ecological Environment, which is very difficult to analyze. Identifying trends and opportunities is very difficult to do because it really depends on the maturity of the environment, there is no standard that has been mutually agreed upon. Included in this ecological environment include the problem of pollution and pollution of the natural environment (physical);

6. Security Environment, especially for Indonesia today, is an aspect that needs to be considered carefully. Security issues greatly affect the life and continuity of an organization, especially those that have activities related to the welfare of the community;

7. Geographic Environment refers to where the organization is located. Geographical conditions, such as disaster-prone, are external factors that can pose a threat to the physical survival of the organization;

8. Competitors Environment, the core business of an organization can be the same as other organizations that have the same activities and businesses. This phenomenon gives rise to competition between organizations, which of course must be considered in conducting the analysis.

Internal Environmental Analysis (ALI) is made by first scanning or observing the internal environment of the organization which includes:

1. Organizational structure, including the composition and placement of personnel.

2. Organizational systems in achieving organizational effectiveness, including the effectiveness of internal communication.

3. Human Resources (HR), Natural Resources (SDA), skilled personnel (skills) at the level of resource empowerment, including

\footnotetext{
8 James B. Whiteker, ibid. p.36-40.
} 
the composition and quality of their human resources.

4. Operational costs and sources of funds.

5. Other factors that illustrate support for the existing organizational performance/mission processes, as well as those that could potentially arise in the internal environment of the organization such as the technology that has been used to date.

Bryson classifies the aspects of the internal environmental analysis into three parts, namely: First, resources which include human resources, economic conditions, information, and competencies; Second, the strategy that is currently being implemented (present strategy) includes a general strategy as well as a specific strategy for each function or its parts; Third, performance (performance) which includes the results that have been achieved (results) and its historical value.

From these two analyzes (ALI and ALE), an overall picture of the situation and condition of the KPD Directorate organization can be obtained from various aspects, internal and external. Starting from the results of the analysis of situations and conditions related to the vision and mission as well as values, then strategic issues and appropriate strategies can be formulated. The analysis of the internal and external environment is carried out simultaneously (simultaneously) because they are two faces of the same coin, mutually interdependent and complementary.

The fundamental problems that we face together and become our big task, both the central and local governments, in reducing poverty and unemployment. Poverty and unemployment are not questions of statistics or numbers, but rather problems concerning the living conditions of our people. Therefore, the government chose to handle it more substantially and fundamentally, and not just a statistical and numerical strategy.

Achieving the targets of economic growth, creating job opportunities, and reducing poverty are joint responsibilities of the central and regional governments. To create high and quality economic growth. Cooperation between regions, synergy, and harmony between regional policies, as well as between central and regional policies, we absolutely must build together and improve, to make our development success.

With this clarity of authority, it is hoped that development in the regions can be carried out even better, and there will be no overlapping in development funding. As a follow-up, the Government has been, is currently updating various sectoral laws to elaborate the powers at the central level, and to clarify the mandatory functions of local governments related to these sectors, such as the law in the field of transportation which has been adapted. in the spirit of regional autonomy.

In order for the national economic development to be better, there is a strong synergy in the preparation and use of the APBN, Provincial APBD, and Regency / City APBD. It is also necessary to accelerate the absorption of the budget, both APBN, and APBD, without sacrificing the principles of clean management and free of corruption, collusion, and nepotism. For this reason, local governments can manage regional finances effectively and efficiently, through good governance with the main pillar duties of transparency, accountability, and participation.

The central government continues to seriously take efficiency measures and save 
unproductive spending. The direction and allocation of capital expenditures are still sharpened according to priorities and also to increase economic growth, create job opportunities, and reduce poverty. Unproductive spending, such as the construction and renovation of central government buildings, as well as the procurement of official vehicles, is very limited. All Regional Governments together with DPRD in compiling their RAPBD, if there is the construction of super magnificent and super luxurious government or state office buildings and facilities, while around residential areas with various basic infrastructure are very adequate. This shows that we have no moral sensitivity, nor do we have empathy for people who are still poor.

\section{ACTUALIZATION OF SOCIAL DEVELOPMENT POLICIES}

According to most respondents, community participation in resolving strategic issues is still very low. One of the factors for the weak public participation is the lack of transparency in the government in solving strategic problems. The public still lacks access to information related to the process of handling strategic problems.

To increase community participation in solving the nation's strategic problems, capacity building is necessary. In the spirit of regional autonomy, without any cooperation between regions, it will be very dangerous because it creates a narrow primordial attitude, regional egoism, and various efforts to solve problems at the border are not compatible. Regional autonomy in the Unitary State of the Republic of Indonesia requires cooperation between regions, in reality, it still creates problems, which, among other things, is due to the absence of a legal basis regulating the mechanism of inter-regional cooperation so that it is not yet patterned. If this issue can be handled properly, it will create harmonious conditions in the management movement between the Autonomous Regions and foster togetherness in overcoming regional development problems in order to improve community welfare.

The scope of cooperation between these regions includes cooperation in overcoming conflicts, cooperation for potential development, and cooperation to achieve mutually beneficial service synergy. For this, of course, we are outraged that a common reference is required based on the cooperation regulations set by the Central Government.

Development disparities have so far occurred between regions within the Autonomous Region, especially between main areas (cities in regency capitals and other fastgrowing areas) and relatively underdeveloped areas (remote island areas, underdeveloped areas, border areas, coastal areas, inland areas, and other special areas). Addressing this issue will help to accelerate the reduction of disparities between development areas, thereby enabling equitable growth in harmony. The scope of the issue of acceleration includes the provision of development service inputs, integrated regional-based development management, and the commitment of regional leaders to handling these underdeveloped areas.

In order to create harmony in regional development, it is necessary to have Regional officials who have a systemic, comprehensive, and visionary attitude. The region-based development approach, which is currently known as the integrated regional development approach, is not yet fully understood by most 
officials in the regions, especially with the fundamental changes in the current constellation of the regional government. If this issue can be handled properly, then efforts to build harmony in regional development will be easier.

The administration of government, especially those related to domestic government politics, requires policy formulations and strategic programs. Levinson warns that the openness to change and the existence of new ideas are determining factors for the success of individuals and organizations. Because of that, Levinson also emphasized matters related to the formulation of later policies, in order to choose managerial or organizational tools that are appropriate to the situation. Based on this strategic policy formulation strategy, several Ministry of Home Affairs strategic policies can be formulated as the basis for formulating strategic programs.

In determining strategic issues as described above, four alternative strategies can be formulated: First, strategies to optimally utilize external opportunities by using the strengths of the Ministry of Home Affairs. Second, strategies to take advantage of existing external opportunities to overcome weaknesses in the Ministry of Home Affairs. Third, the strategy is to utilize the strengths of the Ministry of Home Affairs to deal with threats that could lead to failure in achieving the organization's mission. Fourth, the strategy to temporarily stand by waiting for the development of outside situations until opportunities are obtained while correcting weaknesses within the organizational capacity.

On the basis of this mindset, it can be formulated based on the following criteria: Providing the greatest multiplier effect for mission achievement, technically realistic, time momentum, and cost; Estimates get the response and support of stakeholders; Constraints/obstacles in implementation and compliance with the provisions and policies of the Ministry of Home Affairs. Technical calculations are carried out through scoring based on these criteria, which is then used to determine the chosen strategy.

\section{SOCIAL DEVELOPMENT AND COMMUNITY WELFARE}

The independence of the Indonesian nation, which clearly states its goal of creating a just and prosperous society based on Pancasila, seems to tend to be increasingly blurred from these ideals of independence. One of the indicators is that the form of social justice is not yet visible, it is even more distant. In a world climate that increasingly places liberalism as the mainstream of thought to bring prosperity, economic liberalism with the characteristics of a market economy that is increasingly being used is felt to make Indonesia move further away from the goal of building a welfare state.

Strategic policies and programs are important to be implemented as a scenario learning process that requires depositing beliefs, assumptions, and preconceptions through the process of exchanging ideas, perceptions, desires, and developing dynamics. The existence of radical changes in the system of national governance and the presence of high state institutions need to be addressed by adapting the political and governance system. Changes that occur will raise high hopes for policy changes including the results of these changes so that it will generate dynamics that will contribute positively or negatively to the national political system. The dynamics that have developed are related to the 
implementation of domestic government politics, related to the policies that have been set and the consequences of a policy.

The essence of human life is essential to achieve a high civilization through the availability of the interaction management institution called the state. One element of state administration is carried out through government. In implementing the government, it is done by establishing policies. Government policy is absolutely necessary to ensure the survival of the State as a political entity and to achieve prosperity as well as to accommodate the growing dynamics and plurality (multicultural diversity), maintain the togetherness of fellow nations, through the discretion of autonomy in government, and in the form of special awards. So, when the government gets certain problems in certain areas, it will respond by issuing certain policies by positioning social policies into the mainstream. By making social policy the main agenda, at least a better situation with the previous situation can be quickly realized.

In view of social policy, it is a government decision made to respond to issues of a public nature, namely overcoming social problems or meeting the needs of the general public to improve the quality of human life through the provision of various income allowances, community services, and other social support programs that are realized. in three categories, namely laws and regulations, social service programs, and taxation systems. Strategic intervention through social policy will give birth to social development in a more systematic, measurable manner and become a priority in development.

Community welfare is a reflection of social welfare. According to Segel and Bruzy (1998: 8), "Social welfare is a prosperous condition of society. Social welfare includes health, economic conditions, happiness, and the quality of life of the people ". Meanwhile, according to Midgley (1995: 14) explains that social welfare is a social welfare condition composed of three elements as follows. First, to what extent social problems are controlled, second, to what extent needs are met and, third, how high are opportunities for advancement. These three elements apply to individuals, families, communities, and even entire societies.

Wilensky and Lebeaux (1965: 138) define social welfare as an organized system of social services and institutions, designed to assist individuals and groups to achieve satisfactory levels of life and health. The aim is to create personal and social relationships that give individuals the opportunity to develop their capacities to the widest possible extent and increase their welfare in accordance with the needs of society.

According to Romanyshyn (1971: 3), social welfare can include all forms of social intervention which have a main and direct concern on efforts to improve the welfare of individuals and society as a whole. Social welfare includes the provision of help and processes that are directly related to the healing and prevention of social problems, human resource development, and improvement of the quality of life, including social services for individuals and families as well as efforts to strengthening or improving social institutions.

So that the welfare of society is the fulfillment of the needs of life in a quality manner through the provision of public services. In all regions, it can be observed from the Human Development Index (HDI) as a measure of human development. Where the HDI is a composite index consisting of three 
main components, namely health, education, and income which are combined proportionally into one. The higher the number the better. The measurement of the level of community welfare is based on the Human Development Index (IPM / HDI), which includes aspects of health, education, and income.

The health aspect does not mean only medical facilities that are needed when sick, but also environmental health and cleanliness of food, clothing, and shelter so that residents can live in peace, including water sources, sanitation, security, and other facilities that affect people's lives. The aspect of education is very important because it affects the way of thinking, reasoning power, insight, breadth of knowledge, and the opportunity to get a job so that the assumption arises that the higher the level of education, the higher the quality of human beings. Meanwhile, the income aspect (meeting the needs of life) is important because health and education can only be obtained and improved if you have sufficient income, although, on the other hand, sufficient income depends on the work done and job opportunities to meet the needs of the individual concerned.

The fulfillment of community welfare based on the above indicators is one of the arguments for the effective and efficient implementation of special autonomy in Aceh. In the implementation of special autonomy, local governments must be able to provide public services according to community needs. This is in accordance with the main function of the local government, namely the welfare of the community. The level of community welfare will depend on the level of public services provided by the local government. People demand special autonomy with the argument that they will be more prosperous when the authority for their welfare is left to them.
Related to the position of the local government as an institution that gets legitimacy from the people to achieve prosperity, is the extent to which the regional government is able to be accountable for both the quality and quantity of the outputs it produces so that it can truly meet the needs of the community. For this reason, the people pay taxes and entrust the use of these taxes to people's representatives who are elected through the election mechanism. From here the concept of "No Tax Without Representation" was born.

On the other hand, regional governments that adopt a special autonomy system imply that regional governments in determining the content of autonomy or their authority must be linked to the real needs of their people. Regardless of the extent of regional autonomy, it must be able to produce public services that are correlated with the needs of the people. Local government exists because of the people and for that its main mission is to prosper its citizens. The essence of prospering citizens is to provide public services that truly meet community needs.

In addition to HDI, it can also be linked to the Millennium Development Goals (MDG), where the Indonesian Government has agreed on an agenda for poverty alleviation that must be achieved by 2014 which is measured in numbers, covering eight agendas to be achieved, namely:

1. The eradication of absolute poverty and hunger that is to be achieved by 2015 . The target is people who earn less than 1 dollar a day and people who experience hunger, considering that more than one billion people in the world are still living in these conditions; 
2. Achievements in Basic Education for all boys and girls that want to be achieved by 2015;

3. To empower gender and women's equality, the gender gap can be resolved in 2015 at all levels of education;

4. Reduction of child mortality. Each year 11 million children die and by 2015 it is expected that this will decrease by two thirds;

5. Improving maternal health, in which by 2015 three quarters of maternal deaths due to childbirth will be reduced;

6. Eradicating HIV / AIDS, malaria and other diseases, 40 million people are infected with AIDS and are expected to be resolved by 2015 including the eradication of malaria and other diseases;

7. Environmental Sustainability synergizes development with environmental preservation. By 2015 half the people who are not served drinking water will be served. 2020 saw an increase in slum dwellers;

8. Developing global partnerships for development, developing open trade and financial systems, commitment to implementing good governance, reducing poverty nationally and internationally.

In examining the direction of social policy as an agenda for realizing just and equitable welfare-oriented towards humans in harmony with economic growth which focuses on humans and the quality of life both as individuals and as members of society towards progress and social change through a development process called social policy. Social policy is a government decision made to respond to issues of a public nature, namely overcoming social problems or meeting community needs, which are manifested in three categories, namely laws and regulations, social service programs, and the tax system. Based on this category, it can be stated that every statute, law, or regulation in the region concerning problems and social life is a form of social policy, however, not all social policies are in the form of legislation (Suharto, 2005).

Through special autonomy in Aceh in achieving prosperity, the name development is carried out, a process to make changes towards an increase in the standard of living of the community, from a certain social condition and condition to a social condition that is considered better or more desirable. Siagian (1994) provides an understanding of development as "an effort or series of growth and change efforts planned and carried out consciously by a nation, state, and government, towards modernity in the framework of national building".

At the level of social services, especially the education, health, and community economic sectors, several deficiencies are still found. Including there has been no significant effort in taxation for social development costs. So it is necessary to sharpen social policies through the preparation of follow-up laws, government regulations, and regional regulations that prioritize social development, increase social services, and sources of income to finance social development. 
DAFTAR PUSTAKA

Bryson, John M., Strategic Planning for Public and Non Profit Organizations, San Fransisco: Jossey-Bass Publishrers- Oxford, 1991

Instruksi Presiden Nomor 7 Tahun 1999 tentang Akuntabilitas Kinerja Instansi Pemerintah, Lembaran Negara Republik Indonesia, 1999

Morrisey, L. George, Pedoman Perencanaan Jangka Panjang, Prenhallindo, Jakarta, 1997

Whittaker, B. James, The Government Performance and Results Act of 1993: A mandate for Strategic Planning and Performance Measurement: Verginia: Educational Services Institute, 1995

William A. Levinson, The way of Strategy, ASQC Quality Press, Wisconsin: 1994

-, Perencanaan Stratejik Instansi

Pemerintah, Lembaga Administrasi Negara dan Badan Pengawasan Keuangan dan Pembangunan, Republik Indonesia, 2000

UU Nomor 32 Tahun 2004 tentang Pemerintahan Daerah Lembaran Negara Republik Indonesia, 2004

Mahadam Labolo, Memahami ilmu pemerintahan, Suatu kajian, teori, konsep, dan pengembangannya, (Jakarta, Rajawali Pers 2006)

Muhammad Ryaas Rasyid, Makna Permerintahan, Tinjauan Dari Segi Etika dan Kepemimpinan, (Jakarta, PT Yarsif Wantapone, 1996),

Ancok, Djamaludin, Bahan Bacaan Manajemen Sumber Daya Manusia, Program Pasca Sarjana Program Studi Magister Administrasi Publik, UGM, 2001.

Bois, Samuel, The Art of Awareness, Dubuque, Iowa: Wm. C. Brown, 1978.
Cushway, Barry., Lodge, Derek., Organizational Behaviour and Design: Perilaku dan Desain Organisasi, PT. Elex Media Komputindo, Jakarta, 2002.

Cullen, Ronald B. dan Donald P. Cushman, Transitions to Competitive Government: Speed, Consensus and Performance, Albany, New York: State University of New York Press, 2000.

David, Fred R., Konsep Manajemen Strategis, PT. Prenhallindo, Jakarta, 2002

Davidson, Jeff. (2003). Manajemen Proyek. Yogayakarta: Andi.

Dwiyanto, Agus, Penilaian Kinerja Organisasi Pelayanan Publik, Seminar Kinerja Organisasi Sektor Publik, Kebijakan dan Penerapannya, Jurusan Ilmu Administrasi Negara, Fakultas Ilmu Sosial dan Ilmu Politik, Universitas Gajah Mada, Yogyakarta, 20 Mei 1995.

Dwiyanto, Agus, Reformasi Birokrasi Publik Di Indonesia, Pusat Studi Kependudukan dan Kebijakan Universitas Gadjah Mada, Yogyakarta, 2002.

Gibson, James L., John M. Ivancevich dan James H. Donnelly, Jr., Organization Behaviour, Structure, Processes. Homewood, III: Richard D. Irwin, 1991.

Hersey, Paul., Blanchard, Ken., Manajemen Perilaku Organisasi: Pendayagunaan Sumber Daya Manusia, Penerbit Erlangga, Jakarta, 1995.

Kovach, Kenneth A., Why Motivational Theories Don't Work, S.A.M Advanced Management Journal, Musim Semi, 1980.

Kumorotomo, Wahyudi, Meningkatkan Kinerja BUMN: Antisipasi Terhadap Kompetisi dan Kebijakan Deregulasi, JKAP No. 1, Yogyakarta, 1996. Lubis, Hari dan Huseini, Martani, Teori Organisasi (suatu pendekatan makro), Pusat 
Antar Universitas Ilmu-Ilmu Soisal, 2001).

Universitas Indonesia, 1987.

Lenvine, Charless H, et.al, Public Nastion dan Leo Zwaak, Instrumen

Administration: Challenges, Choices, International Pokok Hak-hak Asasi

Conssequences, Glenview, Illionis: Scott Manusia, (Jakarta, Yayasan Obor Indonesia,

Foreman/Little Brown Higher Education, 1997). 1990.

Lipmann, Walter (1995). Opini Publik. Jakarta:

Yayasan Obor Indonesia.

Pace. R., Wayne, Faules, Don. F, Komunikasi

Organisasi: Strategi meningkatkan Kinerja

Perusahaan, ed: Deddy Mulyana, PT.

Rosdakarya, 1998.

Rahmat, Jalalludin (1999). Psikologi

Komunikasi. Bandung: Remaja Rosda Karya.

Rangkuti, Fredy (2003). Analisis SWOT Teknik Membedah Kasus Bisnis. Jakarta: Gramedia Pustaka Utama.

Robbins, Stephen P., Organizational Behaviour, ed. Ke-4. Englewood Cliffs, N.J.: Prentice Hall, 1972.

Soeharto, Iman (1995). Manajemen Proyek:

Dari Konseptual Sampai Organizasional. Jakarta: Erlangga.

Tosi, Henry L., Jon R. Rizzo dan Stephen J. Carol, Managing Organizational Behaviour, ed. Ke-2 New York: Harper, 1990.

Thoha, Miftah, perilaku Organisasi: Konsep dasar dan Aplikasinya, Rajawali Pers, Jakarta, 1998.

Zeithaml, Valarie A.A Parasuraman dan Leonard L Berry, Delivering Quality Service: Balancing Customer Perceptions and Expectataions, New York: The Free Press, Macmillan Inc, 1990.

Sumitro Djojohadikusumo, Perkembangan Pemikiran Ekonomi, (Jakarta, Yayasan Obor Indonesia, 1991), hal. 29-37.

HAR Tilaar, Paradigma Baru Pendidikan Nasional, (Jakarta, Penerbit Rineka Cipta, 